\title{
Scarabiasis revisited: a case study from Sri Lanka
}

\author{
Priyani Gamage $^{1}$, Anjalie Amarasinghe ${ }^{2}$, Inoka Karunaratne ${ }^{3}$, Rumala Morel $^{2}$, Nalin Nandasiri²
}

\begin{abstract}
Scarabiasis is an ectoparasitic infestation of the gastrointestinal tract by coprophagous beetles. Herein we report scarabiasis from a 3-year-old girl from Sri Lanka, 32 years after the last report in this country. She was treated with metronidazole, lactulose syrup and advised to take hygienic precautions. No further episodes of passing beetles were observed.
\end{abstract}

Ceylon Medical Journal 2021; 66: 53-54

DOI: http://doi.org/10.4038/cmj.v66i1.9359

\section{Introduction}

Scarabiasis is a condition where beetles temporarily infest the gastrointestinal tract without mucosal invasion. It is seen in children living in tropical countries but is rarely reported. Scarabs are identified in the "fly away" from the anus at the time of defecation [1]. Scarabiasis is known among rural Sri Lankans as 'kurumini mandhama' (beetle marasmus) in Sinhala language [2,3]. Herein we report scarabiasis from a 3-year-old girl from Sri Lanka, 32 years after the last report from the country in 1988 [3].

\section{Case presentation}

In September 2020, a 3-year-old girl from Deltota, Kandy District with a history of passing live beetles per rectum presented to the Pediatric Ward of the Base Hospital, Rikillagaskada. Parents noticed that beetles fly away from the child's anus at the time of defecation once every two days for about 6 weeks. Within this period, her mother reported that the number of beetles increased from 2-3 to 10 beetles and the size of the beetles also increased. Child had abdominal cramps, nausea and poor appetite. The child had been previously treated with anthelminthic treatment, but this condition did not improve.

According to the parents the child was defecating in the compound although they have a pit latrine. Also the child often plays in the compound without wearing underwear. The house has a cemented floor and walls made of concrete blocks with an asbestos roof. They do not have cattle. However the father is a vegetable farmer so they use cattle dung as fertilizer. Also the mother uses cattle dung and clay for her fireplace.

During the physical examination the child's height and weight, and weight gain was recorded as normal for her age. Child was afebrile, not pale and had no rashes in the body. Her systemic examination was normal. Full blood count, erythrocyte sedimentation rate (ESR), serum electrolytes, per rectal and fecal examination and ultrasound scan of abdomen were normal.

The child was referred to the Department of Parasitology, Faculty of Medicine, University of Peradeniya, with a live beetle sample. The beetle was morphologically identified as Onthophagus unifasciatus using identification keys [4] and identified dung beetle collection in the Entomology Laboratory of the Department of Zoology, Faculty of Science, University of Peradeniya. The beetle was shiny black and copper colored; head to thorax length $6.82 \mathrm{~mm}$; abdomen width $3.50 \mathrm{~mm}$; thorax width $3.13 \mathrm{~mm}$. Head was subcircular in shape. The finely striated elytra were copper color with yellow markings and had a pair of brown wings (Figure 1).

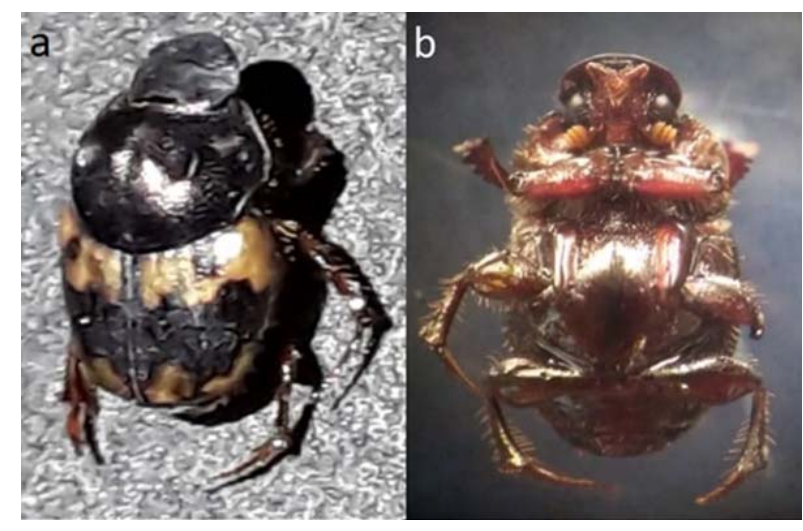

Figure 1.Dorsal (a) and ventral (b) morphology of Onthophagus unifasciatus specimen passed with the child's feces.

${ }^{1}$ Base Hospital, Rikillagaskada, Sri Lanka, ${ }^{2}$ Department of Parasitology, Faculty of Medicine, University of Peradeniya, Sri Lanka, ${ }^{3}$ Department of Zoology, Faculty of Science, University of Peradeniya, Sri Lanka.

Correspondence: RM, e-mail: <rumala.morel@gmail.com>. Received 23 November 2020 and revised version 14 February 2021 accepted 20 March 2021. 
The child was diagnosed with scarabiasis and given metronidazole $100 \mathrm{mg}, 8$ hourly for five days and lactulose syrup for two weeks. Parents were advised to dress her with tight fitting underwear and to use a potty. No further episodes of passing beetles were observed. However, since the child had loss of appetite, her parents have taken her to an indigenous Ayurvedic treatment centre where she was given some oral herbal remedy. The child is now doing well.

\section{Discussion}

Scarabiasis is an ectoparasitic infestation of the gastrointestinal tract by coprophagous beetles. All reported scarabiasis cases to date have identified that infected children invariably belong to a lower socioeconomical background [1]. The child we report was also from a rural village. In our case, ultrasound scan of abdomen, per rectal and fecal examination were found to be normal as in previous studies [1]. Similar to this case, previous cases have also reported patients having poor appetite and abdominal cramps [1,2,3,5].

How the adult beetles or any stage of the lifecycle enters into the human gut is still controversial. Previous studies [1,3] consider the possibility of the larval stage entering through the child's anus. However, it is doubtful that a toddler will remain complacent when a relatively large beetle with coarse limbs crawls up the anus [2]. It is possible that this child accidently ingested dung beetles from the cow dung used as fertilizer. However, a study reported that feeding Onthophagus larvae and beetles to puppies resulted in death of the larvae and the beetles [5].

In Sri Lanka, due to the failure of most Western medical practitioners to consider this condition seriously, parents often seek Ayurvedic treatment [3]. Although scarabiasis was diagnosed and treated in this case the parents had given Ayurvedic treatment to improve the appetite. This arthropod infestation is not a rare occurrence in rural socioeconomically disadvantaged areas in the country [3]. Therefore, it is important for clinicians to be aware of this condition.

\section{Conflicts of interest}

Authors declare that they do not have conflict of interests.

\section{Ethics approval}

We were unable to reach the patient's parents in person to obtain written consent due to Covid-19 pandemic. Therefore all the information regarding the patient was completely anonymised.

\section{Funding}

None.

\section{References}

1. Varghese SM, Austoria AJ, Koshy M, Abraham JM. A rare and interesting case of Scarabiasis. Int J Contemp Pediatr. 2019; 6(6): 2709. DOI: 10.18203/2349-3291.ijcp20194761

2. Rajapakse S. Beetle marasmus. Br Med J (Clinical research ed.). 19814; 283(6302): 1316. DOI: 10.1136/bmj. 283. 6302.1316

3. Edirisinghe JS. Scarabiasis. Trop Doct. 1988; 18(1): 47-8.

4. Arrow GJ. Coleoptera Lamellicornia Part III. Coprinae. The fauna of British India including Ceylon and Burma. New Delhi, India. 1931.

5. Gunawardena K. A Study of Onthophagus unifasciaius Schall (Scarabaedae-Coprinii) and Scarabiasis in Ceylon. Indian J Med Res. 1963; 51(4): 654-0. DOI: https:// www.cabdirect.org/cabdirect/abstract/19642900461 